\title{
Influence of Harvest, Processing, and Substrate in the Germination of Dalbergia nigra Seeds
}

\author{
Leonardo Regnier ${ }^{1,2, a}$ * \\ ${ }^{1}$ Institute of Biosciences, University of São Paulo, São Paulo, Brazil \\ ${ }^{2}$ Department of parks and green areas 2, Secretary of Green and Environment, São Paulo, Brazil \\ aleonardoregnier8@gmail.com
}

Keywords: Forestry seeds, Fabaceae, Seedling production, Jacarandá-da-Bahia

\begin{abstract}
Dalbergia nigra is a Brazilian native species with relevant economic and ecological roles. Due to its indiscriminate exploration, it is an endangered species. Besides the great demand for seedling production, only a few aspects of $D$. nigra germination have been explored. Thus, this study aimed to determine how harvesting immature fruits, fruits processing, and substrate could influence $D$. nigra germination process. Five thousand immature and five thousand mature fruits were evenly distributed between two replicas of each of the 3 treatments: integral fruits, fruits with cut edges, and direct seed sowing in vermiculite. Seeking to evaluate substrate influence over germination, 252 seeds were strewed in the prepared organic substrate. No fruits harvested in visually green appearance germinated under any of treatments. Integral fruits and cut procedure presented the same time for the first germination, almost two times the amount observed to direct seeds sowing. Besides that, the germination rate was not statistically affected. Different substrates also influence the germination pattern, as seen to seed processing when using vermiculite as a substrate, germination starts earlier but the germination rate was not statistically affected. Harvest of Dalbergia nigra green fruits is not an adequate procedure seeking seedling production. The reduction on germination time and better seedling quality, indicate that direct seed sowing procedure is adequate seeking seedling production. Vermiculite substrate gave better results, reducing the time required to germination process. Furthermore, this substrate did not affect the germination rate during this study period.
\end{abstract}

\section{Introduction}

Dalbergia nigra (Vell.) Allemão ex Benth. is a rare and endangered Brazilian forest species [1], [2]. It is also known as "jacarandá-da-Bahia", with natural occurrence in Atlantic Forest from Northeast until the Southeast States. This species is used for making piano and furniture fabrication, also civil construction, and decoration due to its hardwood properties [3], that promoted its worldwide wood use [3]. The indiscriminate exploitation of D. nigra by the wood industry and the destruction of its natural habitat brought this species to Brazil's list of endangered species.

Besides the economic relevance, this species also has an important ecological role as a pioneer, being responsible to initiate recovery of degraded areas due to its great resistance to dry periods and sun exposure [3]. This contributes to its common applications in reforestation programs and also urban afforestation because of its ornamental appearance with delicate leaves and exuberant treetop form [3].

Despite the huge importance of D. nigra, this species propagation's aspects, especially germination and the study of soaking, embryo growth and seedling establishment has been poorly studied [4], [5]. Only a few aspects of germination have been explored such as temperature and basic laboratory used substrate influence over germination [5], [6]. Therefore best propagation methods of D. nigra and other native species are still unknown [4]. Even so, it is essential to know more details about seed development, such as the germination of seeds under distinct environmental conditions.

The growing demand of native Brazilian species for commercial production is another aspect that favors researches focused on the reduction of the time required to seedling production [7]. 
Since basic germination techniques have not been capable of fulfilling the great demand of Brazilian's native seedling production [8], [9]. This context propitiates research of germination and development aspects of Brazilian native species as D. nigra.

Germination conditions, as substrate and harvest procedures studies, are still scarce. The substrate can influence germination since aeration, structure, water retention, pathogenic infestation and other aspects can be highly different [10], [11]. Harvest techniques could provide important reductions in production time. In some species, even green fruits can contain mature seeds, making the harvest of immature fruits an interesting procedure to reduce seedling production time. This technique, also known as early harvesting procedure, is cheaper since all fruits can be harvested at once, besides to enable longer transportation and avoid offering spoiled seeds or fruits to consumers [12]. However, this procedure could result in seed quality loss.

Therefore, this study aimed to determine how harvesting immature fruits, fruits processing, and substrate could influence Dalbergia nigra germination process.

\section{Materials and Methods}

This study was conducted at the Harry Blossfeld plant nursery of São Paulo, situated in Cotia (2336'30.0"S 46 50'48.9"W). According to Köppen's climate classification, the study region presents Cwa, altitude tropical climate [13]. Featuring concentered rains during summer, dry winter, and the highest mean temperature above $22^{\circ} \mathrm{C}$.

Plant material was collected in the west region of São Paulo city, at two separated moments, the end of May and October both of 2018. Immature fruits were gathered directly from the treetop and fallen fruits were collected. In this study, immature fruits were considered all visually green. Plant material was kept in open plastic bags at room temperature during 5 days, seeking to dry the seeds [14] and to recognize the emergence of pathogens or insects. Before the beginning of experiments, a sample of 1550 seeds and 200 cut fruits, and 200 integral fruits were used to the estimation of mean weigh with a Filizola Mf weighing scale.

The study was divided into two steps. First, five thousand immature and five thousand mature fruits were evenly distributed between two replicas of each of the 3 treatments. Immature and mature fruits were submitted to the control treatment consisted of direct sowing of integral fruits (Fig. 1a). While in the second treatment all fruits had their edges around the seed removed with scissors (Fig. 1b). In the third treatment, seeds were removed from the fruits (Fig. 1c) and proceeded to sow. In sequence, fruits and seeds were planted in white trays containing vermiculite as substrate.

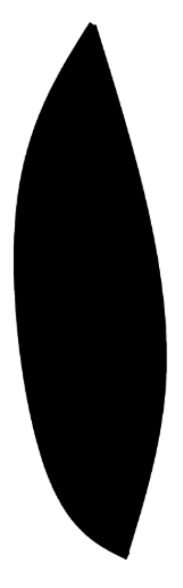

a

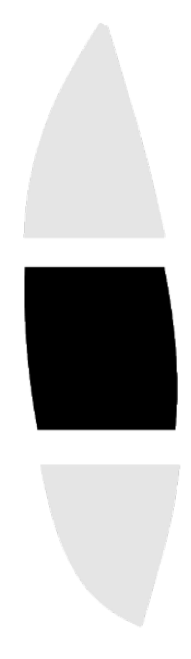

b

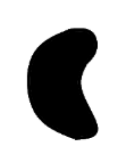

$\underline{1.5 \mathrm{~cm}}$

C

Figure 1. Treatments adopted during the first part of experiments: a) Integral fruits; b) Fruits with edges cut; c) seeds of Dalbergia nigra. Black represents the sowed parts. 
Seeking to evaluate substrate influence over germination, 252 seeds were planted in $280 \mathrm{~cm}^{3}$ greenhouse tube, with a prepared organic-based substrate, composed by 2 liters of local soil, 8 liters of rice husk, 5 liters of Basaplant ${ }^{\circledR}$ forestry substrate, $46.5 \mathrm{~g}$ of Yoorin $\mathrm{K} \AA$ potassium thermosetting fertilizer and $46.5 \mathrm{~g}$ of gradual release fertilizer Osmocote Plus ${ }^{\circledR}$.

After all treatments, the seeds and fruits were kept at greenhouse with white plastic covering and a fogging watering system with periodic activation every 35 minutes. Plant emergence was recorded about 50 days after seeding, with measurements nearly every 7 days.

The evaluation consisted in the use of indexes as mean germination time, also known as mean length of incubation time [15], and the standard deviation was calculated as proposed by Haberlandt in 1875 [16]. Mean germination time defined below:

$$
T_{m}=\frac{N_{g 1} T_{1}+N_{g 2} T_{2}+\cdots+N_{g n} T_{n}}{N_{g 1}+N_{g 2}+\cdots+N_{g n}}
$$

where $T_{m}$ is the mean germination time, the measurement of the mean time required to one seed germination, or the average length of time required for maximum germination of a seed lot; $N_{g 1}$, $N_{g 2}$ and $N_{g n}$ values are the non-cumulative quantities of germinated seeds during specific times $T_{1}$, $T_{2}$ and $T_{n}$, respectively. In this study, time was always presented in days. Respectively, standard deviation (s) noted as:

$$
s=\sqrt{\frac{N_{g 1}\left(T_{1}-T_{m}\right)^{2}+N_{g 2}\left(T_{2}-T_{m}\right)^{2}+\cdots+N_{g n}\left(T_{n}-T_{m}\right)^{2}}{\left(N_{g 1}-1\right)+\left(N_{g 2}-1\right)+\cdots+\left(N_{g n}-1\right)}}
$$

Mean time to stabilize germination $\left(T_{m e}\right)$, also its standard deviation, were calculated using the same rules for mean germination time. However, using the cumulative germination data. Aiming to determinate the mean time required to germination and death rate reach the same amount, providing a stable seedling number on a seed lot.

Synchronization index is associated with the distribution of the relative frequency of germination, the frequency of germination obtained to known $\mathbf{k}$ time is described as [15]:

$$
f_{k}=\frac{N_{g k}}{N_{g 1}+N_{g 2}+\cdots+N_{g n}}
$$

In addition, the synchronization index $(\overline{\mathrm{E}})$ can be obtained by:

$$
\overline{\mathrm{E}}=\left(-f_{1} \log _{2} f_{1}\right)+\left(-f_{2} \log _{2} f_{2}\right)+\cdots+\left(-f_{n} \log _{2} f_{n}\right)
$$

All data were compiled to Excel component of Microsoft Corporation Office pack and represented through graphics and tables. All the statistical tests were executed with individual data of the replicas. Statistical tests were performed using BioEstat 5.0 software. The results were tested by ANOVA and in sequence submitted to Tukey test with a critical $p$-value of $5 \%(p<0.05)$.

\section{Results and Discussion}

\section{Seed weight}

Estimation of seed weight is very important due to its commercial applicability since forestry seeds are usually sold per kilogram. The sample presented a mean weight of 13879.71 seeds per kilo (Table 1), relatively close to other author's estimation of 10000 seeds per kilo [3]. Fruits were about $71 \%$ heavily than seeds, presenting a mean of $0.123 \mathrm{~g}$ per fruit. 
Table 1. Mean weight of fruits and seeds of each treatment.

\begin{tabular}{lc}
\hline Treatment & Mean weight $[\mathrm{g}]$ \\
\hline Fruits & 0.123 \\
Cut fruits & 0.100 \\
Seeds & 0.072 \\
\hline
\end{tabular}

\section{Harvesting Procedure}

Harvesting procedures influenced greatly the germination responses (Fig. 2). No fruits harvested in visually green appearance germinated under any of treatments. Suggesting that if the fruits are harvested in an immature stage of development, seeds are also immature, affecting the germination. Others studies found that visually mature Cassia ferruginea (other species belonging to Fabaceae family) fruits, when harvested from the trees presented lesser germination rates [17]. These authors also mentioned that in general, non-domesticated species could present variable maturation, and gathering fruits directly from the treetop could result in seeds with immature embryos. During embryos maturation of some Fabaceae family members, including $D$. nigra, there is an essential stage when seed cotyledons are transferred to the embryo tissue [18], followed by the drying stage with water content reduction and the beginning of embryo dormancy. Those stages completed, the seed reaches the physiological maturation point, when seeds reached the greater germinative potential [10]. Only after the physiological maturation point seeds can be harvested without affecting their quality. This maturation point is highly variable between species, while some seeds reach it 5 days after the anthesis, others would take about 50 days [10]. The data suggest that D. nigra seeds seem not to reach the maturation point when green fruits are harvested. This study data also corroborates the idea that seed development is not necessarily concatenated with fruit development stages [17].

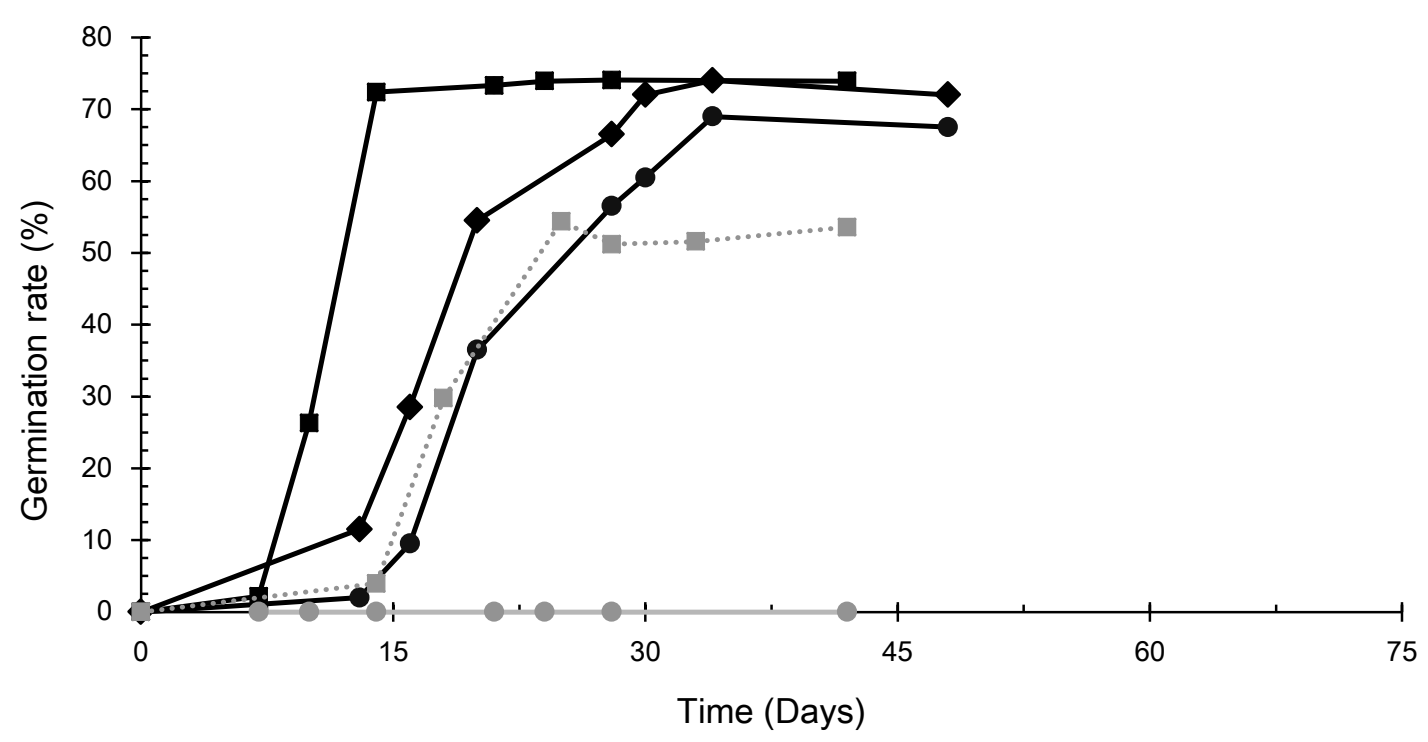

Figure 2. Cumulative seed germination of Dalbergia nigra from green harvested fruits $(\bullet)$, and mature harvested fruit submitted to treatments of direct seed sowing $(\boldsymbol{\square})$, fruits with edges cut $(\diamond)$, and control $(\bullet)$ treatments using vermiculite substrate, and also direct seed sowing in the prepared substrate $(\square)$. 


\section{Fruit Processing}

Fruit processing affected significantly the seed germination process during the study time. Integral fruits and cut procedure presented the same time for the first germination (Table 2), almost two times the amount observed to direct seeds sowing. Time to reach $50 \%$ of germination indicates that this index value reduces gradually according to seed processing procedure. As greater is the processing used with the fruits, the less time it would take for the seed lot to achieve $50 \%$ of its germination. Similar results were found by Lorenzi [3], which indicates that the germination of direct seed sowing of $D$. nigra fruits occurs between 10 and 20 days after seeding. Germination rate slightly increased according to seed processing degree, but was not significantly different between treatments. This suggested that the adopted seed processing methods at this study did not affect the germination rate, but reduced significantly the required time to initiate germination when seeds are directly sown, as seen in Fig. 2. The observed reduction of required time to germination is an important aspect to pay attention to the seedling production process. In addition to that, Lorenzi [3] also emphasize that during germination, seedlings that germinated from whole fruits presented lower quality. Thus, the results indicate that even though the germination rate has not been significantly affected, due to the reduction of the required time to seedling production and better seedling quality, direct seed sowing is relevant processing before sowing.

Table 2. Mean time, in days, for the first germination $\left(t_{0}\right)$, to reach $50 \%$ of germination $\left(t_{1 / 2}\right)$, to stabilize germination $\left(T_{m e}\right)$ and mean germination time $\left(T_{m}\right)$ according to control, cut fruits and seeds sowing procedures. Synchronization index $(\overline{\mathrm{E}})$ and germination rate obtained to study period were also presented.

\begin{tabular}{lcccccc} 
& $\boldsymbol{t}_{\mathbf{0}}$ & $\boldsymbol{t}_{\mathbf{1 / 2}}$ & $\boldsymbol{T}_{\boldsymbol{m}^{ \pm \mathrm{S}}}$ & $\boldsymbol{T}_{\boldsymbol{m} \boldsymbol{e}} \pm \mathrm{S}$ & $\overline{\mathrm{E}}$ & $\begin{array}{c}\text { Germination rate } \\
{[\%]}\end{array}$ \\
\hline Seeds & & & & & & \\
Cut fruits & $7^{\mathrm{a}}$ & $12.06^{\mathrm{a}}$ & $12.71 \pm 0.19^{\mathrm{a}}$ & $30.90 \pm 35.35^{\mathrm{a}}$ & $1.24^{\mathrm{a}}$ & $73.92^{\mathrm{a}^{\mathrm{a}}}$ \\
Control & $13^{\mathrm{b}}$ & $19.11^{\mathrm{b}}$ & $20.28 \pm 0.18^{\mathrm{a}}$ & $30.92 \pm 10.07^{\mathrm{a}}$ & $2.01^{\mathrm{a}}$ & $72^{\mathrm{a}}$ \\
& $13^{\mathrm{b}}$ & $25.83^{\mathrm{b}}$ & $23.72 \pm 0.64^{\mathrm{a}}$ & $32.76 \pm 22.44^{\mathrm{a}}$ & $1.93^{\mathrm{a}}$ & $67.50^{\mathrm{a}}$ \\
\hline
\end{tabular}

* Lowercase letters present the statistical group differences

The first stage of germination is imbibition, when seed absorbs water, a process that restarts the development of the embryo [10]. Thus, water absorption is essential to the germination process. To D. nigra, the data indicated that there is a gradual reduction of germination time according to greater seed processing methods. Probably associated with a greater exposition of seeds to water, the germination process is resumed earlier, requiring less time to the healthy seeds to germinate. Besides that, seed processing did not affect the germination rate obtained during this study period. Pointing out that seed processing only reduces required time to healthy seeds resume the embryo development process but not propitiate a greater number of seeds to germinate.

Synchronization index, numerically, presents the heterogeneity of the seed germination process. Therefore, greater indexes values indicate lesser synchronization between germination processes. There was no statistical difference between the seed processing methods, besides the slight reduction of synchronization indexes of direct seed sowing treatment, indicating greater synchronization. Germination pattern was close in general (Fig. 3) pointing out that seeds processing only reduce the time required for germination occur, but the distribution pattern of germinations is somehow similar. 


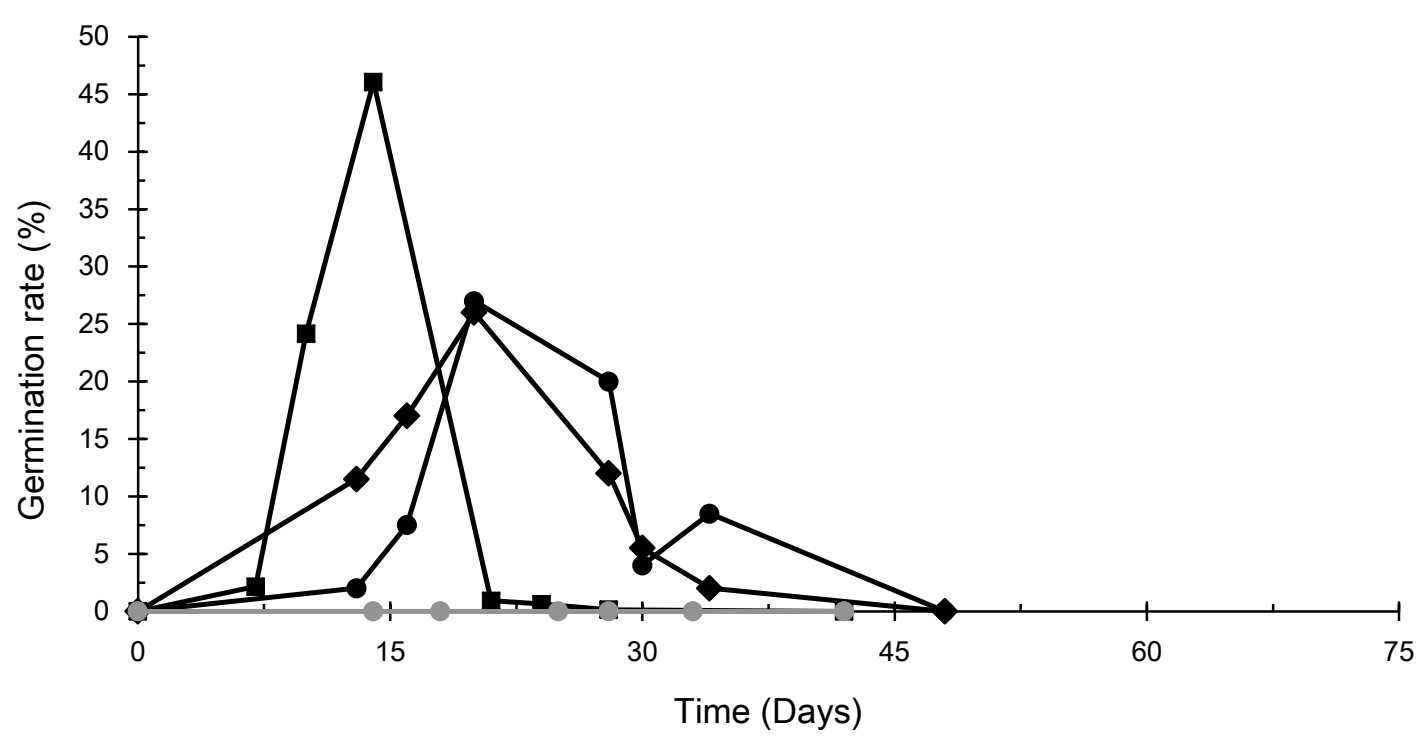

Figure 3. Non-cumulative seed germination of Dalbergia nigra from green harvested fruits ( $\bullet)$, and mature harvested fruit submitted to treatments of direct seed sowing ( $\mathbf{\square})$, fruits with edges cut ( $\bullet)$, and control $(\bullet)$ treatments using vermiculite substrate.

\section{Substrate}

The obtained data indicate that different substrates also influence the germination pattern, as seen to seed processing when using vermiculite as a substrate, germination starts earlier but the germination rate was not statistically affected (Table 3). Substrate influence over germination is a recognized aspect, due to the aeration, structure, water retention, pathogenic infestation, and other aspects which can be highly different between different substrates [8], [10], [11], [14]. Comparisons between usual laboratory substrates as vermiculite, paper, and paper roll have already been done, and vermiculite was the best substrate to germination of D. nigra [6]. The experiment results also show that vermiculite is still the best substrate when compared to the organic-based substrate.

Table 3. Mean time, in days, for the first germination $\left(t_{0}\right)$, to reach $50 \%$ of germination $\left(t_{1 / 2}\right)$, to stabilize germination $\left(T_{m e}\right)$ and mean germination time $\left(T_{m}\right)$ according to vermiculite and organic substrate. Synchronization index $(\overline{\mathrm{E}})$ and germination rate obtained to study period were also presented.

\begin{tabular}{lcccccc}
\hline Indexes & $\boldsymbol{t}_{\mathbf{0}}$ & $\boldsymbol{t}_{\mathbf{1} / \mathbf{2}}$ & $\boldsymbol{T}_{\boldsymbol{m}^{ \pm \mathrm{S}}}$ & $\boldsymbol{T}_{\boldsymbol{m} \boldsymbol{e}} \pm \mathrm{S}$ & $\overline{\mathbf{E}}$ & $\begin{array}{c}\text { Germination } \\
\text { rate [\%] }\end{array}$ \\
\hline Vermiculite & $7^{\mathrm{a}}$ & $12.06^{\mathrm{a}}$ & $12.71 \pm 0.19^{\mathrm{a}}$ & $30.90 \pm 35.5^{\mathrm{a}}$ & $1.24^{\mathrm{a}}$ & $73.92^{\mathrm{a}}$ \\
Organic substrate & $16^{\mathrm{b}}$ & $23.83^{\mathrm{b}}$ & $25.67 \pm 3.16^{\mathrm{a}}$ & $26.27 \pm 8.77^{\mathrm{a}}$ & $1.38^{\mathrm{a}}$ & $53.57^{\mathrm{a}}$
\end{tabular}

* Lowercase letters present the statistical group differences

These results also demonstrate that the vermiculite substrate is very adequate to reduce the germination time required to reach the maximum germination rate when direct seed sowing treatment is adopted. Differing from direct seed sowing in the prepared organic-based substrate (Fig. 4). Besides that, the germination rate obtained to the analyzed period was not significantly different. Vermiculite has chemical and physical characteristics that favored D. nigra germination and adequate seed development, like aeration, water retention and distribution to the seeds [4]. These characteristics can propitiate the reduction of the required time to initiate the germination of the seed lot. 


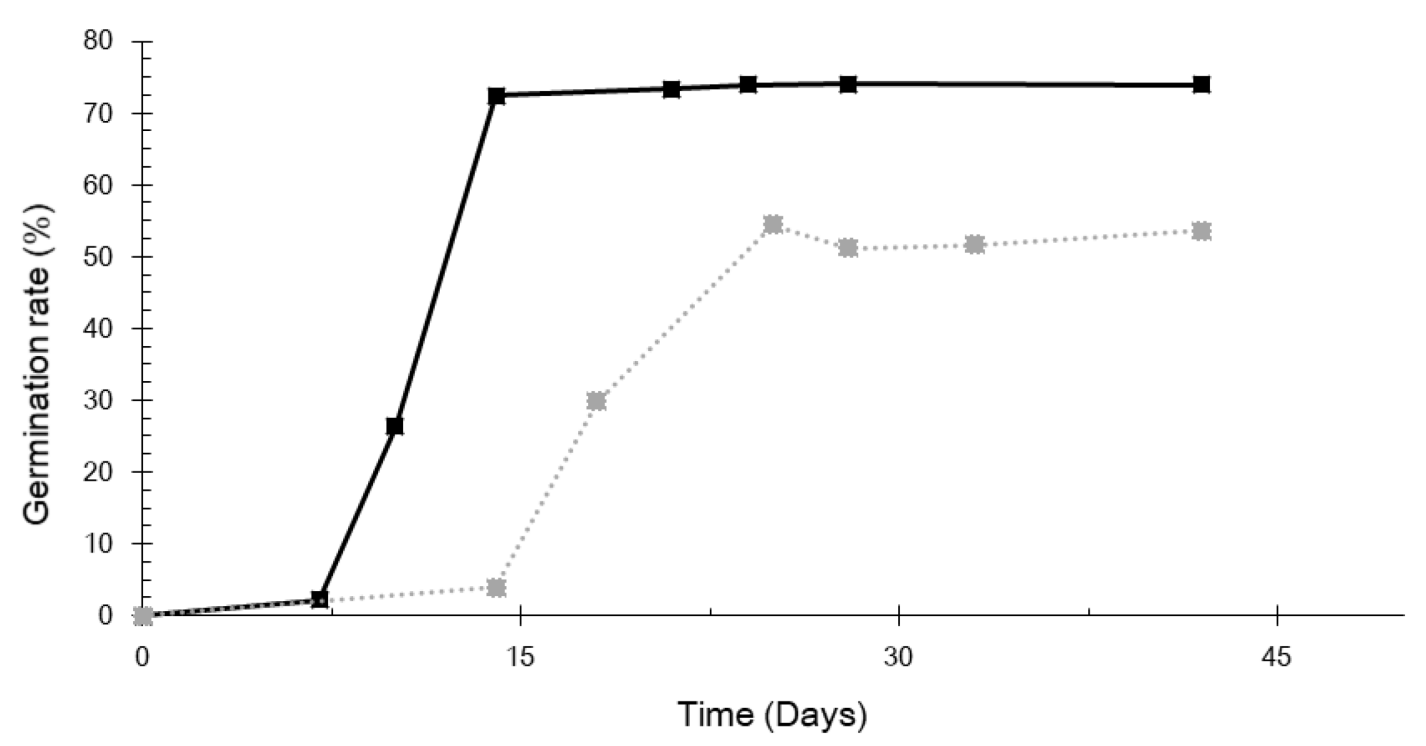

Figure 4. Cumulative seed germination of Dalbergia nigra of direct seed sowing, using vermiculite substrate $(--)$ and prepared substrate $\left({ }^{-} \cdot{ }^{-\cdots}\right)$.

Germination rate observed to this study period is lower than the rate found in the literature, the maximum mean germination rate was $73.92 \%$ when seeds are directly sowed. In general, the literature cites that the germination rate of $D$. nigra is usually higher than $80 \%$ [3]. Moreover, native species present grater regional variations, since those species are not domesticated, and natural populations have been under evolutionary process, this creates great variations depending on studies sampling [14]. There are other factors that can influence greatly the germination rate, providing some bias, since those factors were not controlled during this study experiment. For example, other authors mentioned that seeds of Dalbergia nigra are not influenced by light exposure, but temperature recognizably affects the germination process [5]. Possibly, the experimental conditions were not the most adequate to reach the same germination rates found by those authors.

\section{Conclusions}

Harvest of Dalbergia nigra green fruits is not an adequate procedure seeking seedling production. Direct seed sowing procedure promoted faster germination. None of the evaluated processing methods substantially affected the germination rate. Vermiculite promoted faster germination than the prepared substrate.

\section{Conflict of Interest}

The author declares no conflict of interest

\section{Acknowledgements}

I would like to appreciate Secretaria do Verde e Meio Ambiente, of São Paulo due to its trainee programs, that propitiate experience and opportunities. In addition, the workgroup of Harry Blossfeld Municipal plant nursery, especially my trainee co-workers and Mr. Claudionor. My bosses Leila Borges Proença and Guilherme Brandão do Amaral for making this idea possible, which can make Brazilian's native plant production better. Also Rafaela C. Perez and Juliana de Lemos due to their consistent scientific support and encouragements. 


\section{References}

[1] A.M. de Carvalho, A Synopsis of the Genus Dalbergia (Fabaceae: Dalbergieae) in Brazil, Brittonia. 49 (1) (1997) 87-109

[2] Ministro De Estado Do Meio Ambiente Brasil, Instrução Normativa. 6 (2008) 1-55.

[3] H. Lorenzi, Árvores brasileiras: manual de identificação e cultivo de plantas arbóreas nativas do Brasil, 7th ed. Nova Odessa: Plantarum, Brazil, 2002, pp.89.

[4] G. da M. Ataíde et al., Alterations in seed reserves of Dalbergia nigra ((Vell.) Fr All. ex Benth.) during hydration, J. Seed Sci. 35(1) (2013) 56-63.

[5] F.G.A. Ferraz-Grande, M. Takaki, Temperature dependent seed germination of Dalbergia nigra Allem (Leguminosae), Brazilian Arch. Biol. Technol. 44(4) (2001) 401-404.

[6] A.C.S. de Andrade et al., Substrato, temperatura de germinação e desenvolvimento pósseminal de sementes de Dalbergia nigra, Pesqui. Ag ropecu. Bras. 41(3) (2006) 517-523.

[7] J.A.S. Santos, L.V.A. Pinto, A.J. Pereira, Avaliação do desenvolvimento morfológico inicial de quatro espécies de leguminosas arbóreas sob diferentes substratos, CERNE. 9(1) (2003) 109-118.

[8] J.L. de S. Carvalho Filho et al., Produção de mudas de jatobá (Hymenea courbaril L.) em diferentes ambientes, recipientes e composições de substratos, CERNE. 9(1) (2003) 109-118.

[9] A. de V. Ferraz, V.L. Engel, Efeito do tamanho de tubetes na qualidade de mudas de Jatobá (Hymenaea courbaril L. var. stilbocarpa (Hayne) Lee et Lang.), Ipê-amarelo (Tabebuia chrysotricha (Mart. ex DC.) Sandl.) e Guarucaia (Parapiptadenia rigida (Benth.) Brenan), Rev. Árvore. 35(3) (2011) 413-423.

[10] F. Popiginis, Fisiologia da semente, 2nd ed. Brasília, 1985.

[11] R. Sales Guedes et al., Germinação de sementes de Dalbergia nigra (Vell.) Fr. All., Acta Sci. - Biol. Sci. 33(4) (2011) 445-450.

[12] J.B.C. da Silva et al., Cultivo de Tomate para Industrialização, 2nd ed. EMBRAPA Hortaliças, 2016.

[13] SMA - Sistema de monitoramento agrometereológico, 2018. [Online]. Available: http://sma.fundacaoabc.org/climatologia/classificacao_climatica/sao_paulo. Accessed: 20Oct-2018.

[14] F.C.M. Piña-Rodrigues et al., Parâmetros Técnicos para a produção de Sementes Florestais, 1st ed., UFRRJ: Seropédica, 2007.

[15] M.A. Ranal, D.G. de E. Santana, How and why to measure the germination process?, Rev. Bras. Botânica. 2 (2006) 1-11.

[16] L.G. Laboriau, A germinação das sementes, Programa Regional de Desenvolvimento Científico e Tecnológico Série de Biologia, 1983.

[17] C. C. Martins et al., Método de colheita e superação de dormência na qualidade fisiológica de sementes de Cassia ferruginea, Semin. Agrar. 33(2) (2012) 491-498

[18] I.B. de Aguiar, M.B. Pinã-Rodrigues, F.C.M. Figliolia, Sementes Florestais, Morfologia, Germinação, Produção, Brasília: ABRATES, 1993. 